\title{
IgM associated primary diffuse mesangial proliferative glomerulonephritis
}

\author{
W LAWLER, G WILliaMS, P TARPEY, AND NP MALLICK \\ From the Departments of Pathology and Renal Medicine, Manchester University and Manchester Royal \\ Infirmary, Manchester, UK
}

SUMMARY Twenty-three cases of IgM associated primary diffuse mesangial proliferative glomerulonephritis are presented. In 18, IgM was the sole localising host immunoglobulin, and it was the predominant globulin in five; C3 was also present in 18. Light microscopy revealed variable diffuse and global mesangial proliferation in all cases, with additional focal global sclerosis in 16, focal segmental sclerosis in 15, and small capsular crescents in seven. Material for electron microscopy was available from 19 patients; in 13, occasional intramesangial electron dense deposits were identified, and in 18 there were irregular, rather ill defined areas of increased electron density in mesangial regions. Clinically, 14 patients presented with the nephrotic syndrome, and nine had asymptomatic proteinuria. During follow-up, only 10 patients showed no change in renal function or improved; the remainder showed increasing hypertension and/or renal function deterioration and four developed end stage renal failure.

It is suggested that IgM associated mesangial proliferative glomerulonephritis should be considered as a distinct clinicoimmunopathological entity.

Primary diffuse mesangial proliferative glomerulonephritis, as an entity distinct from both resolving acute diffuse proliferative glomerulonephritis and the glomerulopathies of systemic diseases, has appeared rather insidiously in histopathological classifications of primary glomerulonephritides over the last 10 years. ${ }^{1-14}$ It is essentially a light microscope diagnosis, based on mesangial expansion due to increased cells and matrix without peripheral capillary basement membrane abnormalities. Immunofluorescence findings include a range of combinations of IgG, IgM, complement fractions, and fibrinogen;31516 in many cases, IgA predominates, an association usually considered separately and designated $\operatorname{IgA}$ nephropathy. ${ }^{17-23}$

Recently, a primary mesangial proliferative glomerulonephritis with $\mathrm{JgM}$ predominating on immunofluorescence has been described and considered as a distinct clinicoimmunopathological entity. ${ }^{24} 25$ In this account we have assessed its frequency and significance in biopsy material.

\section{Material and methods}

One hundred and ninety-seven successful non-

Received for publication 31 March 1980 transplant renal biopsies carried out on patients in the Renal Unit at the Manchester Royal Infirmary in the four-year period 1973-6 were reviewed. Seventyone showed some increase in mesangium without uniform peripheral capillary basement membrane thickening. Pathological assessment was followed by analysis of the patients' clinical notes.

In 24 patients, glomerular involvement was considered to be part of a systemic disease or recognised syndrome (eg, systemic lupus erythematosus, Henoch-Schönlein purpura, paraproteinaemia, diabetes mellitus, or Alport's syndrome); the remaining 47 patients were diagnosed as primary diffuse mesangial proliferative glomerulonephritis. In the latter group, immunofluorescence studies disclosed IgM as the sole localising host immunoglobulin in 18, and the predominant globulin in 5; these 23 cases constitute the basis of this report.

Techniques for light, immunofluorescence, and electron microscopy have been described previously. ${ }^{26} 27$

\section{Results}

\section{LIGHT MICROSCOPY}

In all 23 cases, there was variable, diffuse, and global mesangial proliferation (Figs 1 and 2). Occasional 


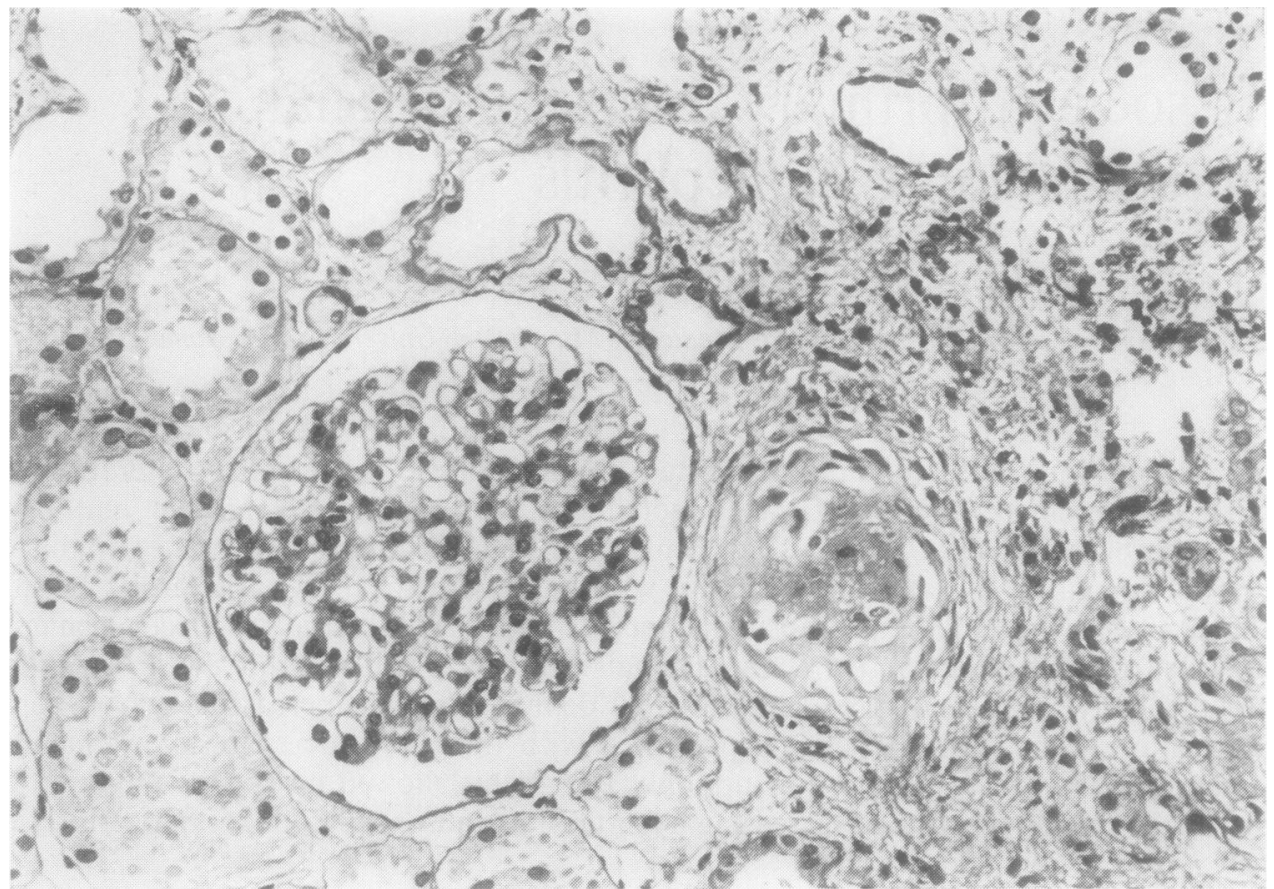

Fig. 1 Case 11. The glomerulus on the left shows uniform global mesangial proliferation with normal peripheral capillary basement membranes; the glomerulus on the right shows global sclerosis. (Periodic acid Schiff $\times 350$ )

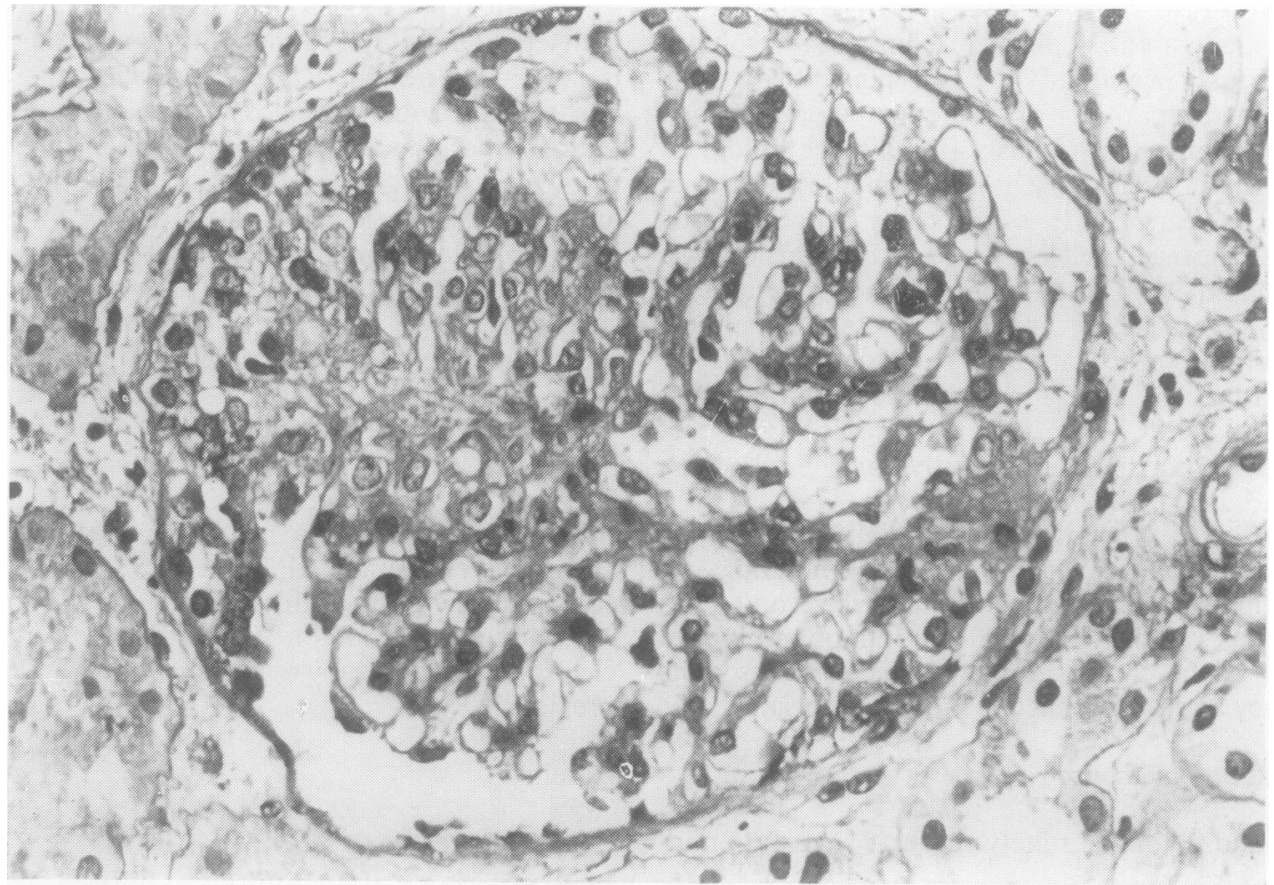

Fig. 2 Case 11. Glomerulus showing global mesangial proliferation with additional segmental sclerosis associated with an overlying capsular crescent (left). $(P A S \times 630)$ 
peripheral capillary basement membranes showed mild, focal, predominantly paramesangial thickening, but circumferential splitting was never seen. In addition, 16 cases showed focal global sclerosis involving over $20 \%$ of glomeruli (Fig. 1), 15 showed focal segmental sclerosis (Fig. 2), and in 7, small capsular crescents were present (Fig. 2). Capsular adhesions or epithelial crescents commonly occurred in glomeruli affected by segmental sclerosis or segmental mesangial proliferation.

\section{IMMUNOFLUORESCENCE}

Of the 18 cases with IgM as the sole localising immunoglobulin, C3 was also present in 14; in three in whom other complement fractions were assessed, all showed $\mathrm{Clq}$ and $\mathrm{C} 4$ without properdin. In five, IgM was the predominant globulin, with IgA in three and IgG in two; $\mathrm{C} 3$ was also identified in four. The IgM, other immunoglobulins, and complement fractions were always diffuse and global in distribution and predominantly mesangial in location (Figs 3 and 4). Staining for fibrin was weakly focally positive in one and equivocal in nine.

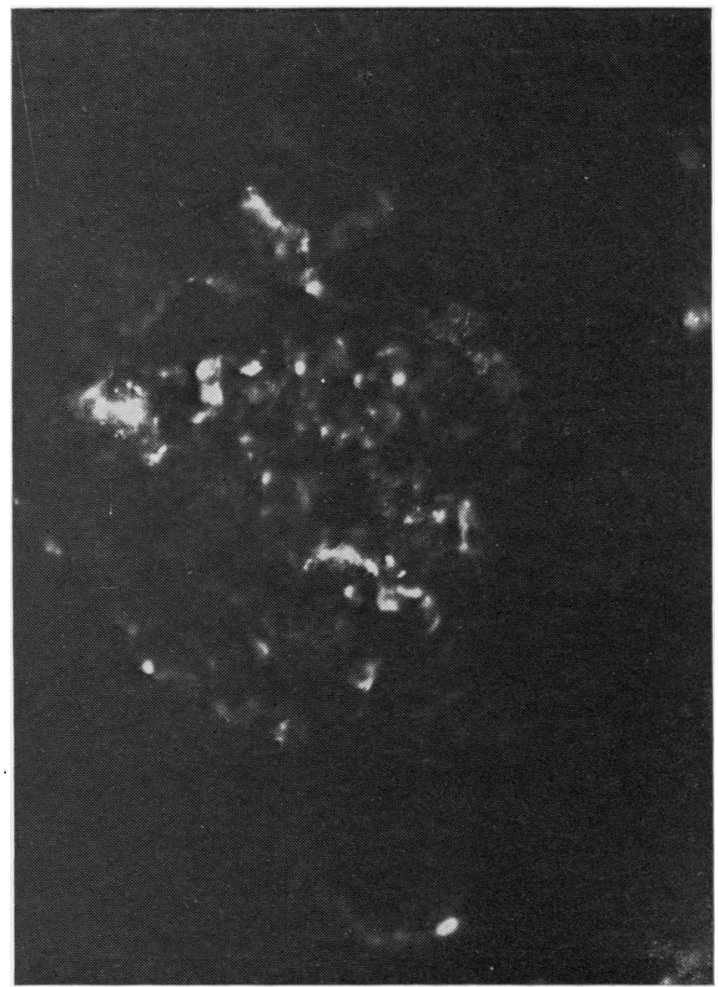

Fig. 3 Case 11. Weak IgM fluorescence almost exclusively confined to mesangial regions. $($ IF $\times 300)$

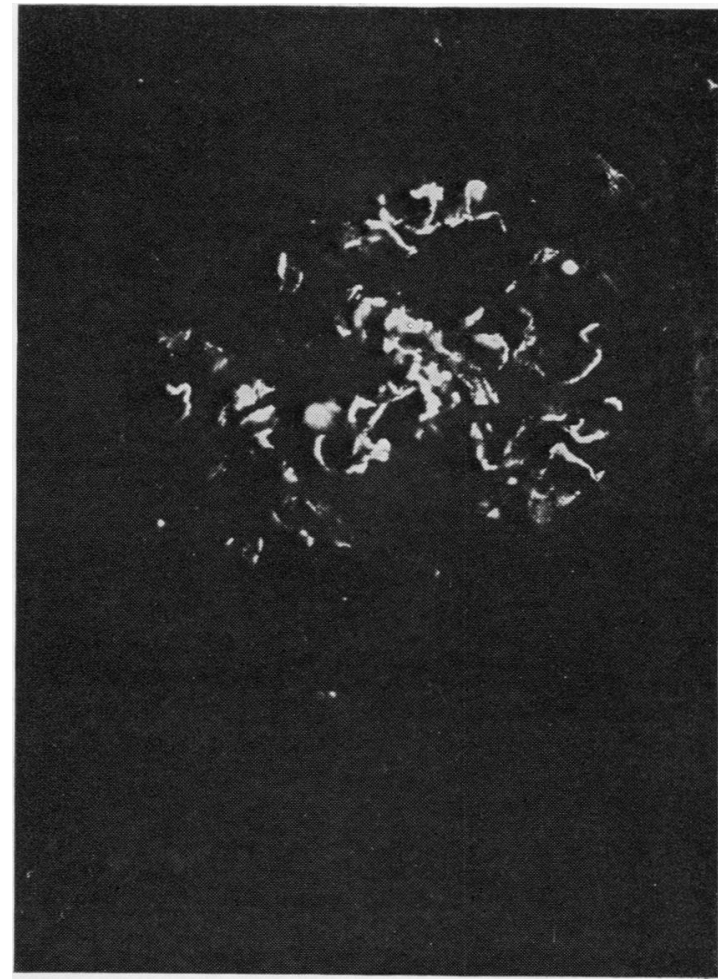

Fig. 4 Case 15. More intense IgM fluorescence r:ainly in mesangial regions but also in several peripheral capillary basement membranes. $($ IF $\times 300)$

ELECTRON MICROSCOPY

Tissue, available from 19 patients, confirmed mesangial proliferation in all cases (Figs 5 to 9). Occasional electron dense deposits were identified in mesangial and paramesangial regions in 13 , but were often rather difficult to distinguish from the increased mesangial matrix (Figs 5 and 6). In 12 of these and in the remaining six, irregular and rather ill defined areas of increased electron density were seen in mesangial regions, but no definite immune complex deposits were identified (Figs 7 and 8). In three cases, occasional subendothelial electron dense deposits were seen in otherwise normal peripheral capillary basement membranes (Fig. 9), but neither intra- nor epi-membranous complexes were present. There was variable epithelial cell foot process fusion, roughly proportional to the patients' proteinuria.

CLINICAL DATA

The clinical data are summarised in Table 1. At presentation, the ages of the 13 men and 10 women ranged from 5 to 53 (mean 29) years; 14 had the nephrotic syndrome, and nine had asymptomatic 


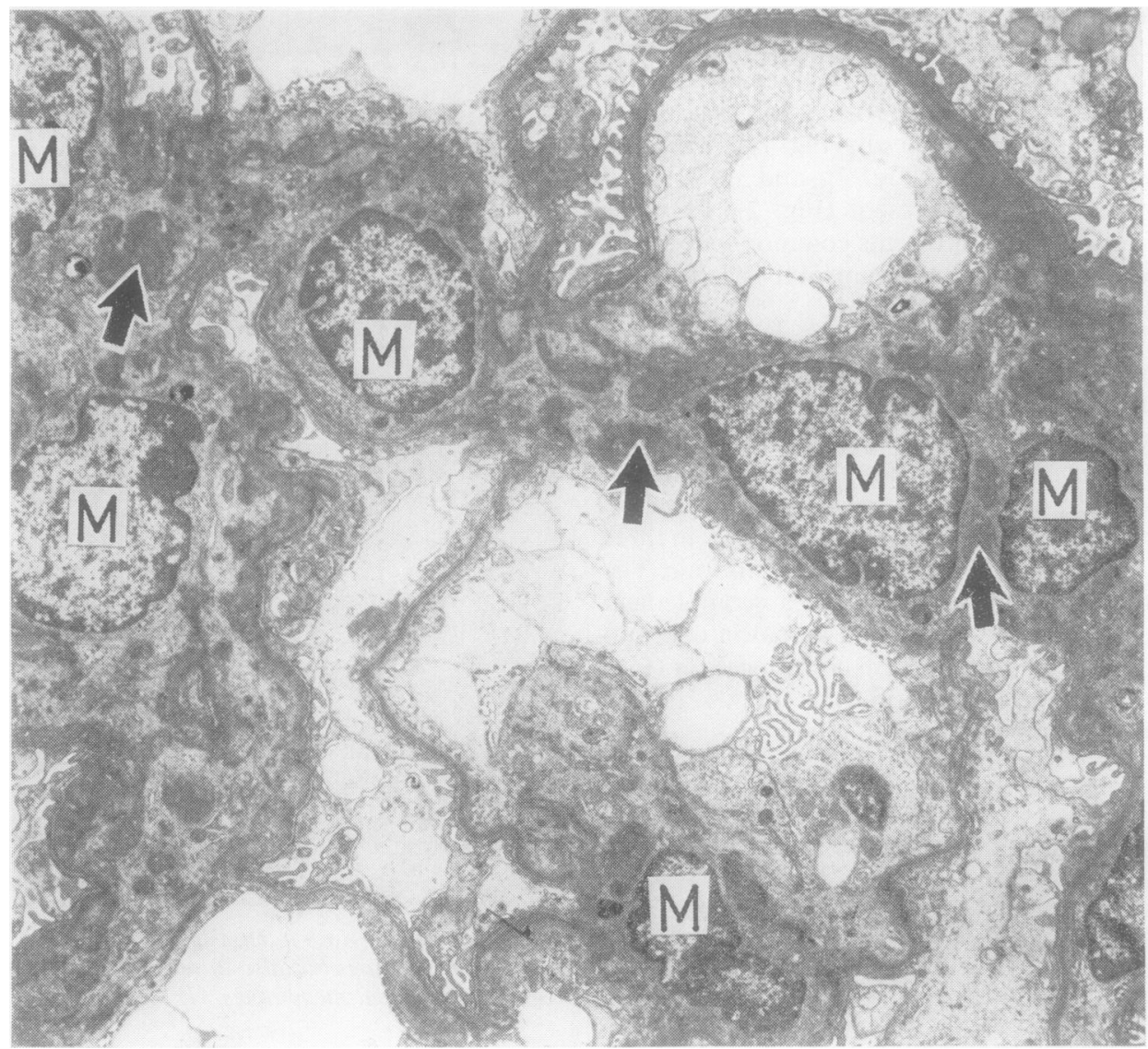

Fig. 5 Case 13. Mesangial regions are considerably expanded by increased cells $(M)$ and matrix and contain several discrete electron dense deposits (arrows). $($ TEM $\times 4750)$

proteinuria; eight had a diastolic blood pressure of $95 \mathrm{~mm} \mathrm{Hg}$ or greater, and one further patient was already on antihypertensive therapy; five had blood ureas above $10 \mathrm{mmol} / \mathrm{l}$; two had microscopic haematuria. None of the patients was HBsAg positive at presentation, and there were no heroin addicts.

Follow-up was from 1 to $16 \frac{1}{2}$ (mean 7.8) years after clinical presentation. Three patients died from unrelated causes (acute myeloblastic leukaemia, cerebral embolism following atrial fibrillation, and myocardial infarction). When their renal status shortly before death is included, follow-up studies revealed that four patients deteriorated into end stage chronic renal failure and death, dialysis, or transplantation; five showed renal functional deterioration and hypertension; four developed increasing hypertension alone; and in ten, renal function either showed no change or improved.

\section{Discussion}

Light and immunofluorescence microscope studies revealed 23 cases of primary diffuse mesangial proliferative glomerulonephritis with IgM as the sole or predominant localising globulin. This association has only recently been documented in the literature, and to date there appear to be only two papers on this subject. ${ }^{24} 25$ Albini et al., ${ }^{28}$ in their review of immunopathology of the kidney, comment that they have encountered a few patients with this entity but give no further details.

In Table 2, the main observations of Cohen et al. ${ }^{24}$ Bhasin et al., ${ }^{25}$ and of this investigation are summarised. Comparisons show that this entity varies in incidence, presumably reflecting variations in criteria for selection. Cohen et al. ${ }^{24}$ reviewed approximately 600 biopsies, excluding five patients with haematuria and predominantly IgM deposits; Bhasin et al. ${ }^{25}$ 
Table 1 Clinical data from the 23 cases

\begin{tabular}{|c|c|c|c|c|c|c|c|c|c|c|c|c|c|}
\hline \multirow{2}{*}{$\begin{array}{l}\text { Series } \\
\text { No. }\end{array}$} & \multirow[t]{2}{*}{$\operatorname{Sex}$} & \multirow{2}{*}{$\begin{array}{l}\text { Age at } \\
\text { onset } \\
(y r)\end{array}$} & \multirow{2}{*}{$\begin{array}{l}\text { Presenting } \\
\text { complaint }\end{array}$} & \multicolumn{4}{|c|}{ At presentation } & \multirow{2}{*}{$\begin{array}{l}\text { Onset to } \\
\text { first } \\
\text { biopsy } \\
\text { (mth) }\end{array}$} & \multirow{2}{*}{$\begin{array}{l}\text { Duration } \\
\text { of disease } \\
\text { (yr) }\end{array}$} & \multicolumn{3}{|c|}{ Status when last seen } & \multirow{2}{*}{ Other comments } \\
\hline & & & & $\begin{array}{l}\text { Blood } \\
\text { pressure } \\
(\mathrm{mm} \mathrm{Hg})\end{array}$ & $\begin{array}{l}\text { Blood } \\
\text { urea } \\
(\text { mmol/l })\end{array}$ & $\begin{array}{l}\text { Proteinuria } \\
(\text { g/day })\end{array}$ & Haematuria & & & $\begin{array}{l}\text { Blood } \\
\text { pressure } \\
\text { (mm Hg) }\end{array}$ & $\begin{array}{l}\text { Blood } \\
\text { urea } \\
(\text { mmolll) }\end{array}$ & $\begin{array}{l}\text { Proteinuria } \\
(\text { g/day })\end{array}$ & \\
\hline 1 & $\mathbf{F}$ & 28 & NS & $155 / 95$ & $12 \cdot 5$ & 9 & Nil & 1 & 11 & $170 / 110$ & $3 \cdot 8$ & 11.5 & \\
\hline 2 & $\mathbf{F}$ & 42 & NS & $150 / 95$ & $7 \cdot 6$ & $6-7$ & Nil & 1 & 6 & $120 / 70$ & $5 \cdot 4$ & $\mathrm{Nil}$ & \\
\hline 3 & $\mathrm{~F}$ & 33 & PrU \& & & & & & & & & & & \\
\hline & & & $\mathbf{H} / \mathbf{T}$ & $140 / 90 \mathrm{~T}$ & 5.8 & 13 & $\mathrm{Nil}$ & 8 & 5 & $140 / 110 \mathrm{~T}$ & $6 \cdot 3$ & 14 & Lost to FU \\
\hline 4 & $\mathrm{~F}$ & 23 & NS & $120 / 80$ & $8 \cdot 1$ & $5-6$ & Nil & 1 & $4 \frac{1}{4}$ & $110 / 70$ & $3 \cdot 5$ & Nil & Lost to FU \\
\hline 5 & $\mathbf{M}$ & 44 & $\operatorname{PrU}$ & $190 / 110$ & $8 \cdot 3$ & $1-2$ & Nil & 1 & 1 & - & - & - & $\begin{array}{l}\text { Acute } \\
\text { myeloblastic } \\
\text { leukaemia }\end{array}$ \\
\hline 6 & $\mathbf{F}$ & 52 & PrU & $130 / 70$ & $6 \cdot 1$ & $1-2$ & Nil & 3 & 2 & $\mathbf{N}$ & $7 \cdot 3$ & $1 \cdot 1$ & $\begin{array}{l}\text { Atrial fibrillation. } \\
\text { Cerebral embolus } \\
\text { No SABE }\end{array}$ \\
\hline 7 & $\mathbf{M}$ & 33 & PrU & $130 / 80$ & $4 \cdot 7$ & $3-4$ & Nil & 9 & 6 & $130 / 95$ & $7 \cdot 9$ & 1 & \\
\hline 8 & $\mathbf{M}$ & 38 & NS & $150 / 90$ & $4 \cdot 6$ & $11-27$ & Nil & 2 & 9 & $175 / 100$ & $10 \cdot 9$ & 13 & \\
\hline 9 & $\mathbf{M}$ & 44 & NS & $165 / 100$ & $21 \cdot 3$ & $7-8$ & Mi & 1 & $2 \frac{1}{2}$ & $180 / 100$ & $26 \cdot 8$ & $4 \cdot 4$ & $\begin{array}{l}\text { Myocardial } \\
\text { infarction }\end{array}$ \\
\hline 10 & $\mathbf{M}$ & 16 & NS & $150 / 110$ & $12 \cdot 0$ & 17 & Nil & 2 & 5 & $130 / 90 \mathrm{~T}$ & $10 \cdot 1$ & $16 \cdot 5$ & \\
\hline 11 & $\mathbf{M}$ & 5 & PrU & $\mathbf{N}$ & $\mathbf{N}$ & $1-4$ & $?$ & 162 & $14 \frac{1}{2}$ & - & - & - & $\begin{array}{l}\text { CRF. } \\
\text { Transplanted }\end{array}$ \\
\hline 12 & $\mathbf{M}$ & 37 & NS & $120 / 90$ & $8 \cdot 2$ & $7-16$ & Nil & 6 & 11 & - & - & - & CRF. Died \\
\hline 13 & $\mathbf{M}$ & 15 & NS & $130 / 80$ & $5 \cdot 0$ & $2-9$ & Nil & 2 & 33 & $120 / 70$ & $5 \cdot 7$ & Nil & \\
\hline 14 & $\mathbf{M}$ & 16 & NS & $150 / 90$ & 3.7 & $10 \cdot 12$ & Nil & 8 & $4 \frac{1}{4}$ & $120 / 70$ & $3 \cdot 6$ & $1-2$ & \\
\hline 15 & $\mathbf{F}$ & 42 & NS & $130 / 80$ & $4 \cdot 4$ & $4-8$ & $\mathrm{~N}$ II & 29 & $9 \frac{1}{4}$ & $140 / 80$ & 3.9 & $0 \cdot 4$ & \\
\hline 16 & $\mathbf{M}$ & 18 & NS & $170 / 90$ & $9 \cdot 6$ & $20-25$ & $\mathrm{Mi}$ & 22 & $3 \frac{1}{2}$ & - & - & - & CRF. Dialysis \\
\hline 17 & $\mathbf{M}$ & 16 & NS & $160 / 95$ & $10 \cdot 3$ & $20-25$ & Nil & 121 & 16 & $155 / 100$ & $5 \cdot 3$ & 1 & \\
\hline 18 & $\mathbf{F}$ & 23 & $\operatorname{PrU}$ & $135 / 95$ & $4 \cdot 0$ & 4 & $\mathrm{Nil}$ & 8 & $15 \frac{1}{2}$ & - & - & - & CRF. Dialysis \\
\hline 19 & $\mathbf{F}$ & 38 & NS & $130 / 90$ & $5 \cdot 6$ & 9.17 & Nil & 2 & 7 & $150 / 100 \mathrm{~T}$ & $8 \cdot 1$ & 5 & \\
\hline 20 & $\mathbf{M}$ & 19 & $\operatorname{PrU}$ & $160 / 105$ & 5.5 & $3-4$ & $?$ & 3 & $16 \frac{1}{2}$ & $160 / 100 \mathrm{~T}$ & $6 \cdot 3$ & 0.5 & \\
\hline 21 & $\mathbf{F}$ & 53 & NS & $160 / 90$ & $10 \cdot 6$ & $10-14$ & Nil & 8 & 5 & $180 / 110 \mathrm{~T}$ & $18 \cdot 2$ & $1 \cdot 5$ & \\
\hline 22 & $\mathrm{~F}$ & 18 & PrU & $120 / 80$ & $5 \cdot 6$ & 14 & Nil & 39 & $10 \frac{1}{2}$ & $150 / 90$ & $4 \cdot 1$ & $4 \cdot 5$ & \\
\hline 23 & $\mathbf{M}$ & 16 & PrU & $140 / 90$ & $4 \cdot 7$ & 3 & Nil & 96 & 11 & $140 / 90 \mathrm{~T}$ & $4 \cdot 2$ & 0.7 & \\
\hline
\end{tabular}

$\mathrm{NS}=$ nephrotic syndrome; $\mathrm{PrU}=$ asymptomatic proteinuria; $\mathrm{H} / \mathrm{T}=$ hypertension $; \mathrm{T}=$ on antihypertensive chemotherapy; $\mathrm{Mi}=$ microscopic haematuria FU $=$ follow-up; $C R F=$ end stage chronic renal failure; $N=$ normal; $S A B E=$ subacute bacterial endocarditis.

The first 18 cases had IgM alone on immunofluorescence; cases 19 and 20 also had IgG, and cases 21-23 also had IgA.

reviewed 180 biopsies but gave no details of selection. In our series, transplant biopsies were excluded, and there were few biopsies from children. Differences in sex incidence are difficult to explain; when the three series are considered together, it appears to be slightly more common in males (M:F 26:20). Age variation at onset presumably also reflects selection, but it seems predominantly a disease of children and young adults.

On light microscopy, a constant finding is variable diffuse mesangial proliferation without uniform peripheral capillary basement membrane thickening. Focal global sclerosis is quite common. Focal segmental sclerosis is more so in our series than in either of the others. Focal glomerulosclerosis was excluded because IgM was diffuse and global and not focal and segmental, juxtamedullary glomeruli were not selectively involved, 'hyalinosis' was not seen, and there were no intraglomerular foam cells. We encountered occasional small and/or early capsular crescents in seven cases; in neither of the other series were they mentioned. In all three series, tubulointerstitial lesions (tubular atrophy, dilatation or hyaline degeneration and interstitial fibrosis or non-specific chronic inflammation) are mild, reflecting glomerular sclerosis and proteinuria; likewise, vascular hyalinisation is mild and reflects the systemic blood pressure.

On immunofluorescence all cases show diffuse, global, predominantly mesangial IgM. Lesser amounts of similarly distributed IgA and/or IgG have also been demonstrated in a few biopsies. In most cases, $\mathrm{C} 3$ has been identified, but the deposition of other complement fractions is poorly documented. Cohen et al. ${ }^{24}$ stated that ' $\mathrm{C} 4$, when present, resembled the pattern of $\mathrm{C} 3$ deposits' but gave no further details; Bhasin et al. ${ }^{25}$ found that ' $\mathrm{Clq}$ was negative in the three cases that were tested'. In our series, complement fractions other than C3 were analysed in only three cases, in whom C1q and C4 but not properdin were found. On this limited evidence, it is impossible to draw conclusions about the pathway of complement activation. Identification of fibrin/fibrinogen was fairly common in the other two series; in our series, it was found in only one case, although equivocal in nine others.

Ultrastructurally, mesangial proliferation is con- 


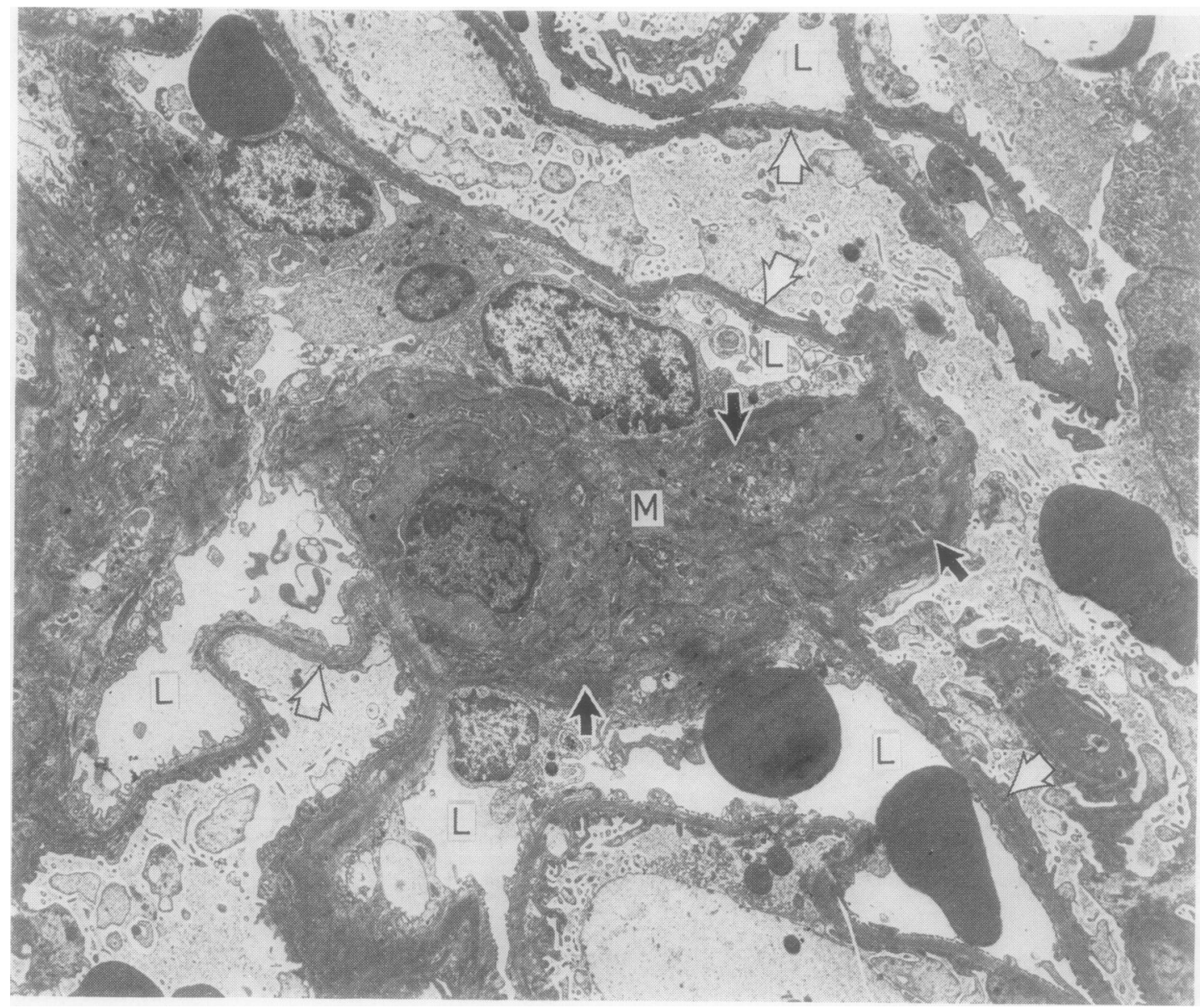

Fig. 6 Case 7. This mesangial region $(M)$ is expanded largely by an increase in matrix. Occasional electron dense deposits are seen (arrows). Normal peripheral capillary basement membranes surround capillary lumina $(L)$, but there is extensive epithelial cell foot process fusion (open arrows). (TEM $\times 5225)$

firmed, but well defined intramesangial discrete granular electron dense deposits were identified in only half the cases, despite diffuse and global mesangial deposition of IgM. In many of these, and in most of the remainder however, there were ill defined, less granular electron dense areas which merged with the mesangial matrix. Glomerular capillary basement membranes show mild, focal, irregular thickening and occasional paramesangial subendothelial electron dense deposits but no circumferential mesangial interposition.

Clinically, when the three series are considered, all except one (who had intermittent macroscopic haematuria) of the 46 patients presented with either a nephrotic syndrome $(69.6 \%)$ or asymptomatic proteinuria $(28 \cdot 2 \%)$. Hypertension at presentation was quite common $(17 / 46 ; 37.0 \%)$; microscopic haematuria $(7 / 44 ; 15.9 \%)$ and some renal function impairment, as indicated by a reduced creatinine clearance or a raised blood urea $(6 / 46 ; 13.0 \%)$, were less common.

During follow-up none of the patients of either Cohen et al. ${ }^{24}$ or Bhasin et al. ${ }^{25}$ showed any deterioration in renal function or increasing hypertension. In contrast, only 10 of the 23 patients $(43.5 \%)$ in our series showed no change or improved; four $(17.4 \%)$ showed increasing hypertension, five $(21 \cdot 7 \%)$ showed some renal function deterioration and hypertension, and four $(17.4 \%)$ developed end stage chronic renal failure. These differences may be explained by longer 


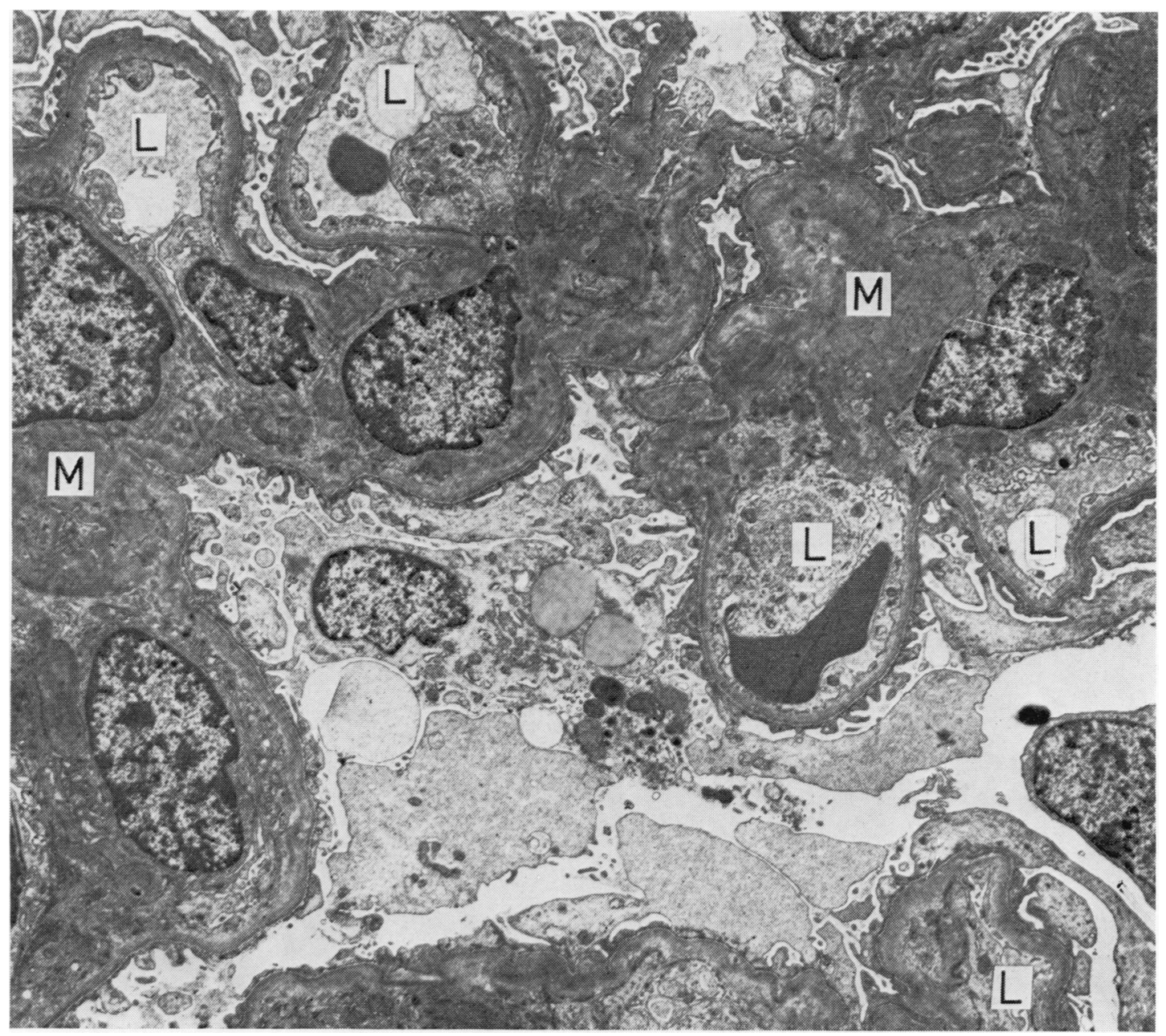

Fig. 7 Case 2. Mesangial regions $(M)$ are expanded by cells and matrix. Several rather ill defined areas of increased electron density are seen, but no discrete immune complexes can be identified. Peripheral capillary basement membranes surrounding capillary lumina $(L)$ are normal, but epithelial cell foot processes show considerable fusion. $(T E M \times 4750)$

periods of follow-up in our series in that most of our patients who developed increasing hypertension with or without some renal function impairment did so many years after presentation, and $3 \frac{1}{2}, 11,14 \frac{1}{2}$, and 15 (mean 11) years elapsed before our four patients developed end stage chronic renal failure. It therefore appears that whereas the short-term prognosis in IgM associated mesangial proliferative glomerulonephritis is good, the long-term outlook must be much more guarded.

The aetiology and pathogenesis of this entity are unknown. It is not surprising, however, that circulating immune complexes containing host IgM localise in glomerular mesangial regions. Germuth and
Rodrigue ${ }^{29}$ have shown experimentally that small, soluble complexes of molecular weight 300000500000 daltons are located predominantly in peripheral capillary basement membranes, while intermediate, less soluble complexes of molecular weight between 500000 and several million daltons are invariably found in mesangial regions. IgM has a molecular weight of 900000 daltons, and thus its size precludes formation of small, soluble complexes. Germuth and Rodriguez ${ }^{29}$ also noted that it is only in extremely large antigen excess that intermediate, less soluble complexes are formed with IgM. Although the source of antigens in this disease is unknown, it is possible that those which preferentially 


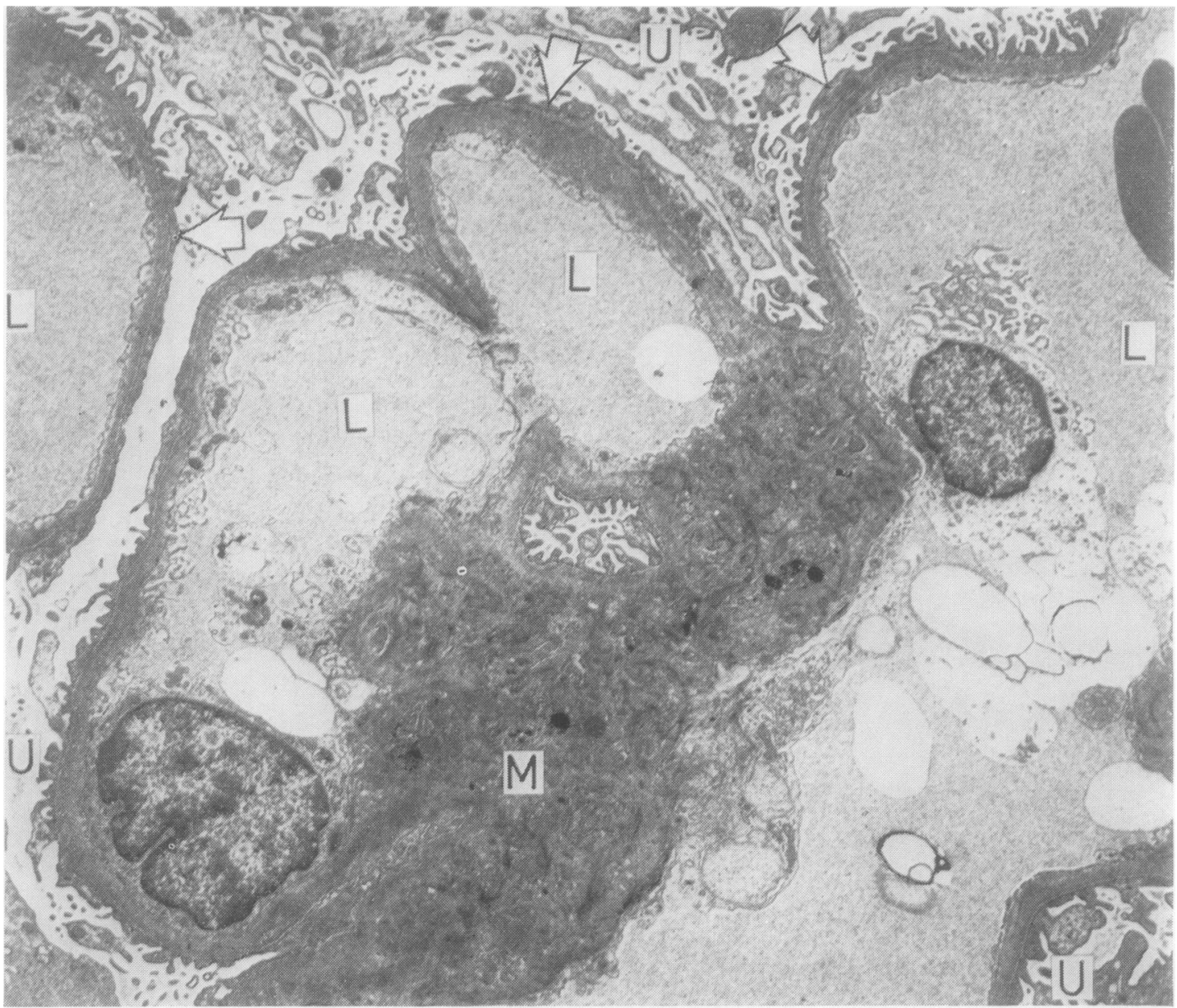

Fig. 8 Case 5. In this mesangial region (M), expansion is mainly due to increased matrix. There are several ill defined areas of increased electron density but no discrete immune complexes. Peripheral capillary basement membranes are normal; epithelial cell foot processes show extensive fusion (open arrows). Also shown are capillary lumina $(L)$ and urinary spaces $(U) .(T E M \times 5225)$

generate an IgM immune response (eg, the common antigen of enterobacteria) are involved, or that abnormalities of the host immune system, such as those described in nude mice, may contribute. ${ }^{28}$

\section{References}

${ }^{1}$ Churg J, Habib R, White RHR. Pathology of the nephrotic syndrome in children. A report for the international study of kidney disease in children. Lancet 1970;1:1299302 .
${ }^{2}$ Habib R, Kleinknecht C. The primary nephrotic syndrome of childhood. Classification and clinicopathologic study of 406 cases. Pathol Annual 1971;6:417-74.

${ }^{3}$ Morel-Maroger L, Leathem A, Richet G. Glomerular abnormalities in non-systemic diseases. Am J Med 1972; 53:170-84.

${ }^{4}$ White RHR. Mesangial proliferative glomerulonephritis in childhood. In Kincaid-Smith P, Mathew TH, Becker EL, eds. Glomerulonephritis. Morphology, Natural History and Treatment. Vol 1. New York: Wiley and Sons, 1973: 383-91.

sieniawska M, Wierzbowska-Lange B, WróblewskaKalivzewska M, Korniszewska J, Kruś S, Gawlik Z. Clinical and morphological correlations in mesangial glomerulonephritis in children. Pol Med Sci Hist Bull 1975;15:23-8. 


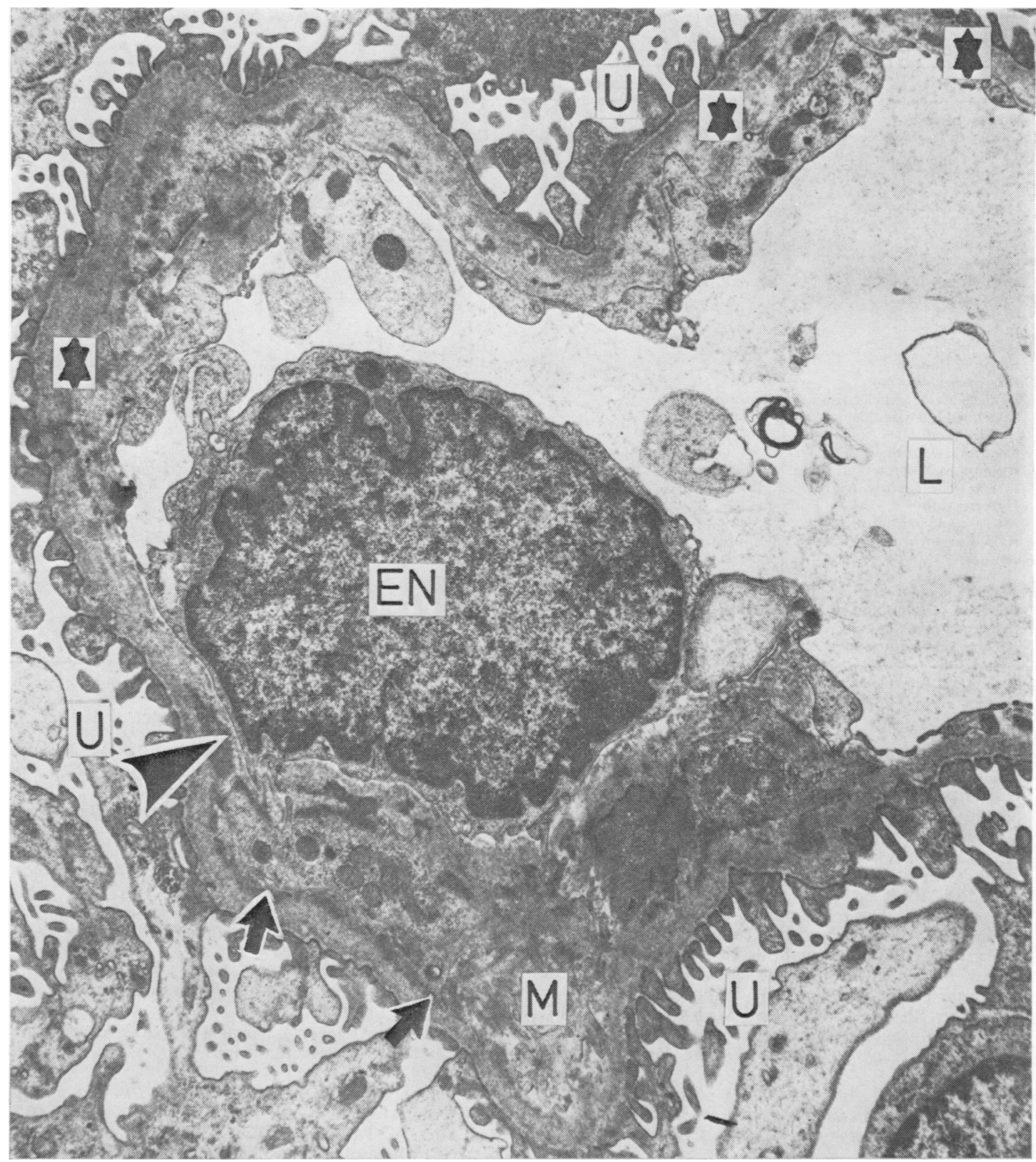

Fig. 9 Case 6. Only the edge of a mesangial region $(M)$ is illustrated. There are several intramesangial electron dense deposits (arrows), one paramesangial subendothelial deposit (arrowhead), and a few peripheral subendothelial deposits ( $\star$ ). The peripheral capillary basement membrane is otherwise normal, and there is mild focal epithelial cell foot process fusion. EN-endothelial cell nucleus; $L$-capillary lumen; $U$-urinary space. $(T E M \times 11250)$

${ }^{6}$ Fischbach H. The morphologic course of different glomerulonephritides (examination of repeat biopsies in 264 patients). Curr Top Pathol 1976;61:155-201.

7 Thoenes GH. The immunohistology of glomerulonephritis-distinctive marks and variability. Curr Top Pathol 1976;61 :61-106.
${ }^{8}$ Bohle A, Eichenseher N, Fischbach $\mathrm{H}$, et al. The different forms of glomerulonephritis. Morphological and clinical aspects, analyzed in 2500 patients. Klin Wochenschr 1976;54:59-73.

${ }^{9}$ Fischbach $\mathrm{H}$, Bohle A, Meyer D, et al. The morphological and clinical course of the different forms of glomerulone- 
Table 2 A comparison of histological, immunofluorescence, ultrastructural, and clinical features of reported cases of IgM associated primary diffuse mesangial proliferative glomerulonephritis

\begin{tabular}{|c|c|c|c|}
\hline & Cohen et al. ${ }^{24}$ & Bhasin et al. ${ }^{25}$ & This series \\
\hline Total No. of cases & 12 & 11 & 23 \\
\hline Incidence in biopsy series $(\%)$ & $12 / 600(2)$ & $11 / 180(6 \cdot 1)$ & $23 / 197(11 \cdot 7)$ \\
\hline Age at onset (mean)-years & $1 \cdot 5-59(28)$ & $1 \cdot 8-23(8 \cdot 2)$ & $5-53(29)$ \\
\hline \multicolumn{4}{|l|}{ On light microscopy } \\
\hline Focal global sclerosis & $4 / 12$ & $5 / 11$ & $16 / 23$ \\
\hline Focal segmental sclerosis & 0 & $1 / 11$ & $15 / 23$ \\
\hline \multicolumn{4}{|l|}{ On immunofluorescence } \\
\hline IgM & $12 / 12$ & $11 / 11$ & $23 / 23$ \\
\hline $\mathrm{C} 3$ & $11 / 12$ & $3 / 11$ & $18 / 23$ \\
\hline $\mathrm{Clq}$ & ND & $0 / 3$ & $3 / 3$ \\
\hline $\operatorname{IgA}$ & $2 / 12$ & 5111 & $3 / 23$ \\
\hline IgG & $1 / 12$ & $5 / 11$ & $2 / 23$ \\
\hline Fibrin/fibrinogen & $3 / 12$ & $6 / 11$ & $1 / 23$ \\
\hline \multicolumn{4}{|l|}{ On electron microscopy } \\
\hline Definite mesangial electron dense deposits & $2 / 9$ & $4 / 11$ & $13 / 19$ \\
\hline \multicolumn{4}{|l|}{ At presentation } \\
\hline Nephrotic syndrome & $9 / 12$ & $9 / 11$ & $14 / 23$ \\
\hline Asymptomatic proteinuria & $3 / 12$ & $1 / 11$ & $9 / 23$ \\
\hline Intermittent macroscopic haematuria & $0 / 12$ & $1 / 11$ & $0 / 23$ \\
\hline Hypertension & $3 / 12$ & $5 / 11$ & $9 / 23$ \\
\hline Microscopic haematuria & $3 / 12$ & $2 / 11$ & $2 / 21$ \\
\hline Raised serum creatinine/raised blood urea & $1 / 12$ & $0 / 11$ & $5 / 23$ \\
\hline \multicolumn{4}{|l|}{ Follow-up } \\
\hline Duration (mean)-years & $0 \cdot 5-4(1 \cdot 5)$ & $0 \cdot 75-14 \cdot 1(4 \cdot 7)$ & $1-16.5(7 \cdot 8)$ \\
\hline To chronic renal failure & 0 & 0 & $4 / 23$ \\
\hline Function deterioration and hypertension & 0 & 0 & $5 / 23$ \\
\hline Increasing hypertension & 0 & 0 & $4 / 23$ \\
\hline No change or improved & $12 / 12$ & $11 / 11$ & $10 / 23$ \\
\hline
\end{tabular}

$\mathrm{ND}=$ not documented

phritis. Klin Wochenschr 1976;54:105-16.

${ }^{10}$ Glassock RJ, Bennett CM, Cohen AH, Zamboni L. The glomerulopathies. In Brenner BM, Rector FC Jr, eds. The Kidney, vol 2. Philadelphia: Saunders, 1976;9411078.

11 Jenis EH, Lowenthal DT. Kidney Biopsy Interpretation. Philadelphia: FA Davis Co, 1977.

12 Meadows R. Renal Histopathology. A Light, Electron and Immunofluorescent Microscopy Study of Renal Disease. 2nd ed. Oxford: Oxford University Press, 1978.

13 Turner DR. Glomerulonephritis. In Anthony PP, Woolf N, eds. Recent Advances in Histopathology, No. 10. Edinburgh: Churchill Livingstone, 1978;235-57.

${ }^{14}$ Waldherr R, Gubler MC, Levy M, Broyer M, Habib R. The significance of pure diffuse mesangial proliferation in idiopathic nephrotic syndrome. Clin Nephrol 1978;10: 171-9.

${ }^{15}$ Burkholder PM. Atlas of Human Glomerular Pathology. Correlative Light, Immunofuorescence and Ultrastructural Histology. Hagerstown, Maryland: Harper and Row, 1974.

16 Larsen S. Immune deposits in generalised mesangioproliferative glomerulonephritis. Fluorescent microscopy findings correlated to symptoms, clinical course and immunosuppressive therapy. Acta Pathol Microbiol Scand A 1978;86:543-52.

${ }^{17}$ Berger J. IgA glomerular deposits in renal disease. Transplant Proc 1969;1:939-44.

18 Lowance DC, Mullins JD, McPhaul JJ. Immunoglobulin A (IgA) associated glomerulonephritis. Kidney Int 1973; 3:167-76.

19 Lowance DC, Mullins JD, McPhaul JJ. IgA-associated glomerulonephritis. Int Rev Exp Pathol 1977;17:143-72.
${ }^{20}$ Davies DR, Tighe JR, Jones NF, Brown GW. Re:urrent haematuria and mesangial IgA deposition. J Clin Pathol 1973;26:672-7.

${ }^{21}$ McCoy RC, Abramowsky CR, Tisher CC. IgA nephropathy. Am J Pathol 1974;76:123-40.

${ }^{22}$ Sissons JGP, Woodrow DF, Curtis JR, et al. Isolated glomerulonephritis with mesangial IgA deposits. $\mathrm{Br}$ Med J 1975;3:611-4.

${ }^{23}$ Lawler W, Williams G, Tarpey P, Acheson EJ, Mallick NP. IgA localisation in glomerular diseases. $J$ Clin Pathol 1977;30:914-24.

${ }^{24}$ Cohen AH, Border WA, Glassock RJ. Nephrotic syndrome with glomerular mesangial IgM deposits. Lab Invest 1978;38:610-19.

${ }^{25}$ Bhasin HK, Abuelo JG, Nayak T, Esparza AR. Mesangial proliferative glomerulonephritis. Lab Invest 1978;39: 21-9.

${ }^{26}$ Williams G. A Colour Atlas of Renal Diseases. London: Wolfe Medical Books, 1973.

27 Lawler W, Tarpey P, Williams G, Acheson EJ, Mallick NP. Diseases and histological normality of the renal glomerulus: a clinicopathological study. J Clin Pathol 1976;29:380-97.

28 Albini B, Brentjens JR, Andres GA. The Immunopathology of the Kidney. London: Arnold, 1979.

${ }^{29}$ Germuth FG Jr, Rodriguez E. Immunopathology of the Renal Glomerulus. Boston: Little, Brown and Co, 1973

Requests for reprints to: Dr W Lawler, Department of Pathology, University of Manchester, Stopford Building, Oxford Road, Manchester M13 9PT, UK. 